\title{
Vulvovaginal Atrophy
}

National Cancer Institute

\section{Source}

National Cancer Institute. Vulvovaginal Atrophy. NCI Thesaurus. Code C154264.

A condition associated with decreased estrogen production, characterized by dryness,

inflammation, and itching of the vulva and vaginal tissues. It may also be associated with dysuria and dyspareunia. 